\title{
RUSSIAN BANKING SECTOR IN APRIL 2013
}

\author{
M.Khromov
}

In April 2013, the Russian banking sector was driven by the same principal trends that were observed in the first quarter of the year. Real sector lending kept slowing down in spite of higher growth rates in household savings. In addition, allowances for provisions for losses on loans and other assets began to have an increasingly inhibitory effect on the financial efficiency of the Russian banking sector.

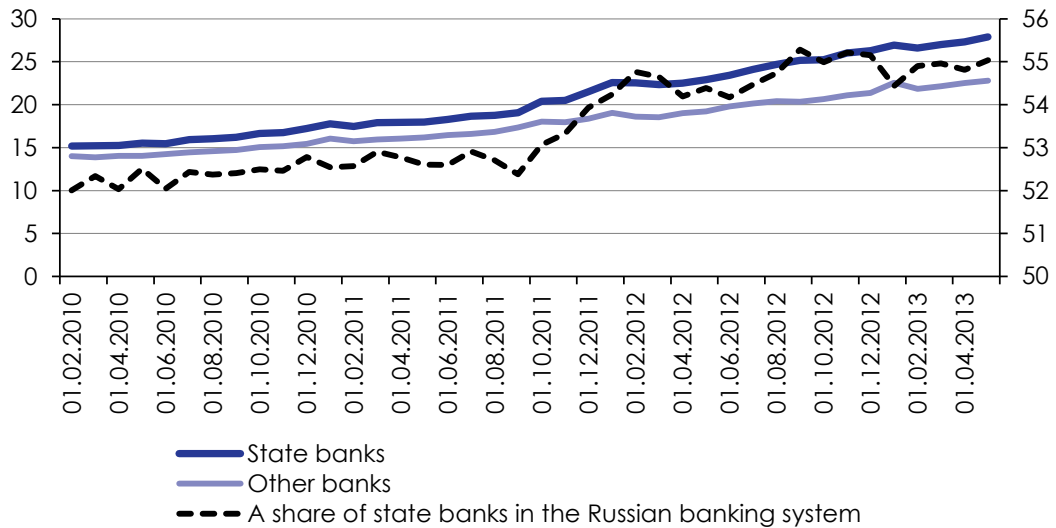

Fig. 1. Dynamics in state and other banks' assets (Rb trillion), and a share of state banks in the assets (\%, right-hand grid)

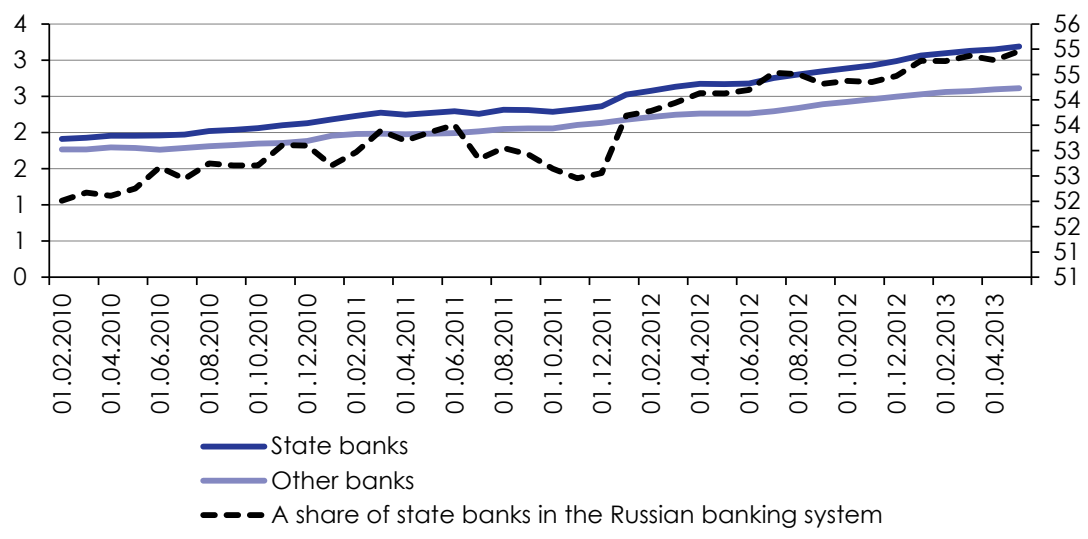

Fig. 2. Dynamics in state and other banks' equity capital (Rb trillion), and a share of state banks in capital (\%, right-hand grid)
Total assets in the Russian banking sector increased $1.7 \%$ in April 2013, gaining Rb 870bn in absolute terms and reaching $\mathrm{Rb} 50.7$ trillion in total volume. The assets in the Russian banking system increased $19.0 \%$ over the past 12 months. Annual growth rates ranged within 18 to $19 \%$ over the first four months of the year. This means that early in the year the Russian banking system saw approximately the same growth rates as in the preceding year.

Banks' equity capital increased $1.0 \%$ in April 2013. Profit remained the principal source of equity growth. Given capitalized profits of previous periods, banks' profit increased $1.5 \%$ during the month, whereas capital and surplus increased no more than $0.5 \%$.

Russian banking sector's profit amounted to Rb 84bn in April 2013, being equal to the average value during the past six months. However, banks' net allowances for provisions for losses on loans and other assets kept growing. They grew up to $\mathrm{Rb} 50 \mathrm{bn}$ in volumes in April 2013, being highest over the past year and a half.

\section{Fundraising}

The growth in household bank deposits which was reported in the previous review continued in April 2013. Household bank deposits reached their highest growth value of $3.1 \%$ (Rb 458bn) during the month. Ignoring year-end peak gains, it was the highest growth rates in bank deposits since the spring of 2010. Annual growth rates reached 21.0\%, thereby resuming the values of the fall of 2011.

Balances of corporate accounts were reduced by $0.4 \%$ (-Rb $51 \mathrm{bn})$ in response to seasonal tax payments to the federal budget during the month. Nevertheless, annual growth rates in this type of liabilities increased up to $12.1 \%$. However, it is too soon to speak about any steady growth dy- 
namics in corporate accounts and deposits.

A shift from current accounts in favor of term deposits was observed in the term structure of corporate accounts and deposits in April 2013. Balances of settlement and current accounts contracted $3.1 \% \quad$ (Rb 359bn), whereas deposits increased $2.5 \%$ (Rb 296bn). As a result, term deposits accounted for more than $55 \%$ of total corporate accounts and deposits at banks, reaching a new highest.

Annual growth rate in bank retail loans in arrears dropped to $36 \%$ at the end of April 2013. Unsecured loans declined faster than others, falling from their 2012 summertime peak values of more than $60 \%$ down to $47 \%$ at the end of the first quarter of 2013.

Slowed down bank lending in the retail market was followed by growth in borrowing costs. For example, weighted average cost of retail loans was $16.5 \%$ p.a. in Q1 2012 against $17.7 \%$ p.a. in Q1 2013, being higher than the pre-crisis values, despite a markedly lower inflation.

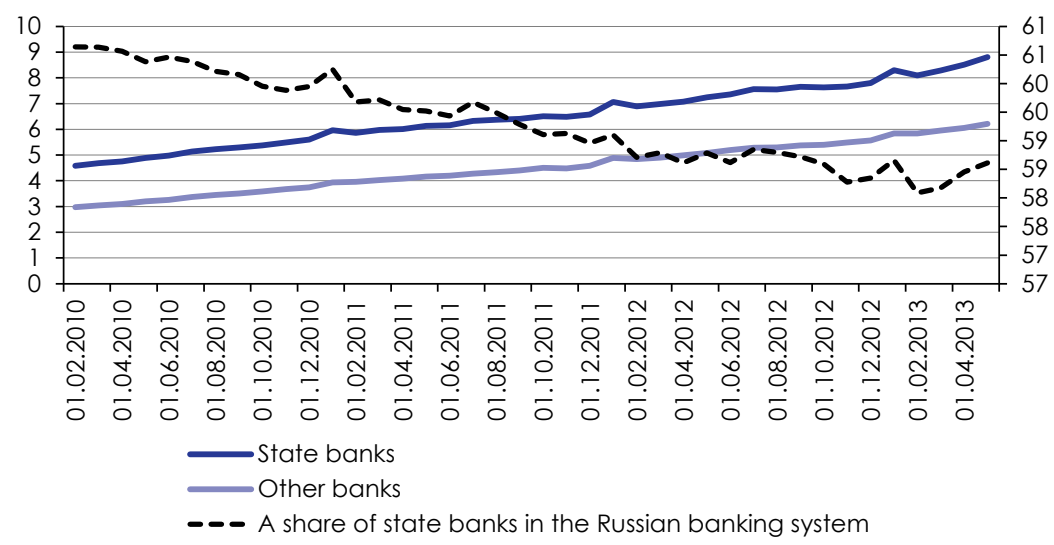

Fig. 3. Dynamics in state and other banks' retail deposits (Rb trillion), and a share of state banks in the retail deposit market (\%, right-hand grid)

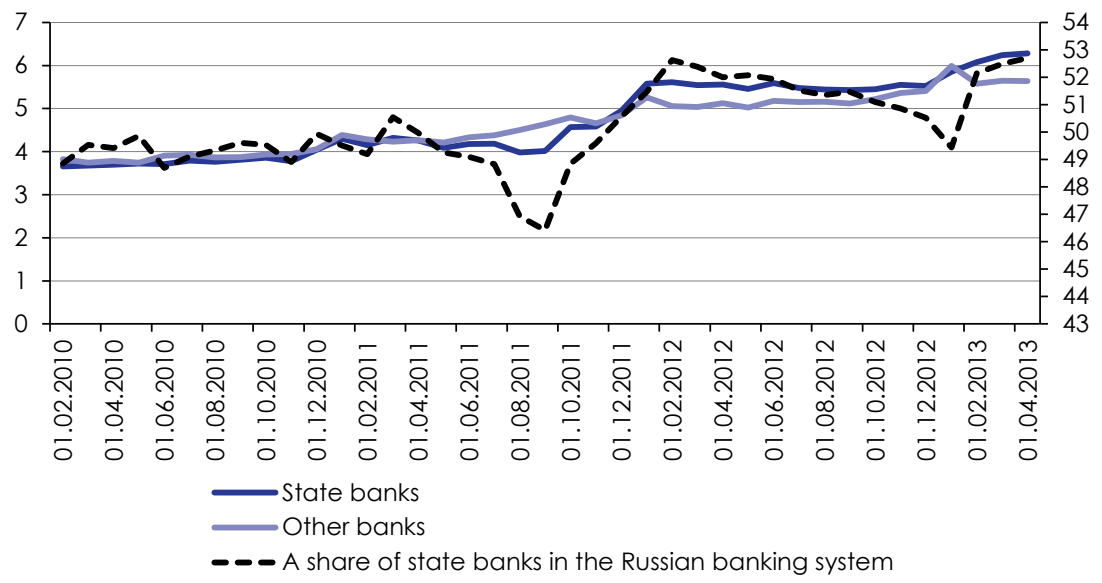

Fig. 4. Dynamics in corporate accounts with state and other banks (Rb trillion), and a share of state banks in the corporate account market (\%, right-hand grid)

Table 1

RUSSIAN BANKING SYSTEM'S STRUCTURE OF LIABILITIES (AT MONTH END), AS PERCENTAGE OF TOTAL

\begin{tabular}{|c|c|c|c|c|c|c|c|c|c|c|c|c|}
\hline & 12.08 & 12.09 & 12.10 & 12.11 & 03.12 & 06.12 & 09.12 & 12.12 & 01.13 & 02.13 & 03.13 & 04.13 \\
\hline Liabilities, Rb trillion & 28022 & 29430 & 33805 & 41628 & 41533 & 44266 & 45861 & 49510 & 48429 & 49165 & 49839 & 50693 \\
\hline Equity & 14.1 & 19.3 & 18.7 & 16.9 & 17.5 & 16.8 & 16.9 & 16.2 & 16.8 & 16.7 & 16.7 & 16.6 \\
\hline $\begin{array}{l}\text { Loans from the Bank } \\
\text { of Russia }\end{array}$ & 12.0 & 4.8 & 1.0 & 2.9 & 3.5 & 5.1 & 5.1 & 5.4 & 4.5 & 4.5 & 4.5 & 4.4 \\
\hline Interbank operations & 4.4 & 4.8 & 5.5 & 5.7 & 5.1 & 4.8 & 5.1 & 5.6 & 5.4 & 5.4 & 5.4 & 5.0 \\
\hline Foreign liabilities & 16.4 & 12.1 & 11.8 & 11.1 & 10.2 & 11.3 & 11.0 & 10.8 & 10.5 & 10.6 & 10.4 & 10.8 \\
\hline $\begin{array}{l}\text { Retail accounts } \\
\text { and deposits }\end{array}$ & 21.5 & 25.9 & 29.6 & 29.1 & 29.4 & 29.4 & 28.7 & 28.9 & 29.1 & 29.3 & 29.6 & 30.0 \\
\hline $\begin{array}{l}\text { Corporate accounts } \\
\text { and deposits }\end{array}$ & 23.6 & 25.9 & 25.7 & 26.0 & 25.7 & 24.0 & 23.3 & 24 & 24.1 & 24.2 & 23.9 & 23.4 \\
\hline $\begin{array}{l}\text { Accounts and deposits of } \\
\text { government agencies and } \\
\text { local government authori- } \\
\text { ties }\end{array}$ & 1.0 & 1.0 & 1.5 & 2.3 & 1.4 & 1.5 & 2.5 & 1.6 & 1.1 & 1.0 & 1.4 & 1.9 \\
\hline Outstanding securities & 4.1 & 4.1 & 4.0 & 3.7 & 4.8 & 4.5 & 4.8 & 4.9 & 5.2 & 5.3 & 5.2 & 5.2 \\
\hline
\end{tabular}

Source: Central Bank of Russia, IET's estimates. 


\section{Loans issued}

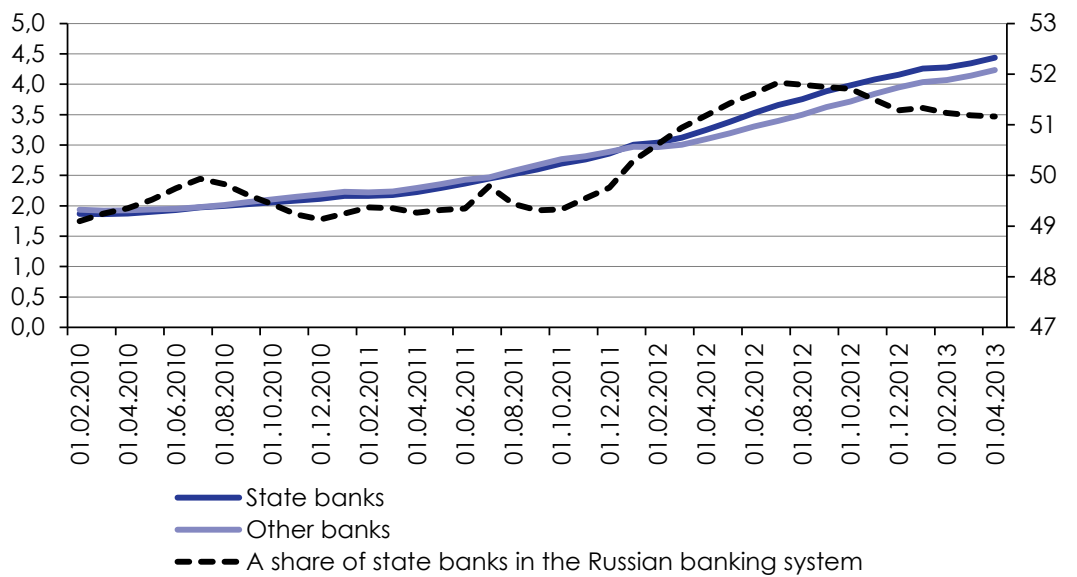

Fig. 5. Dynamics in state and other banks' retail loans, (Rb trillion), and a share of state banks in the retail loan market (\%, right-hand grid)

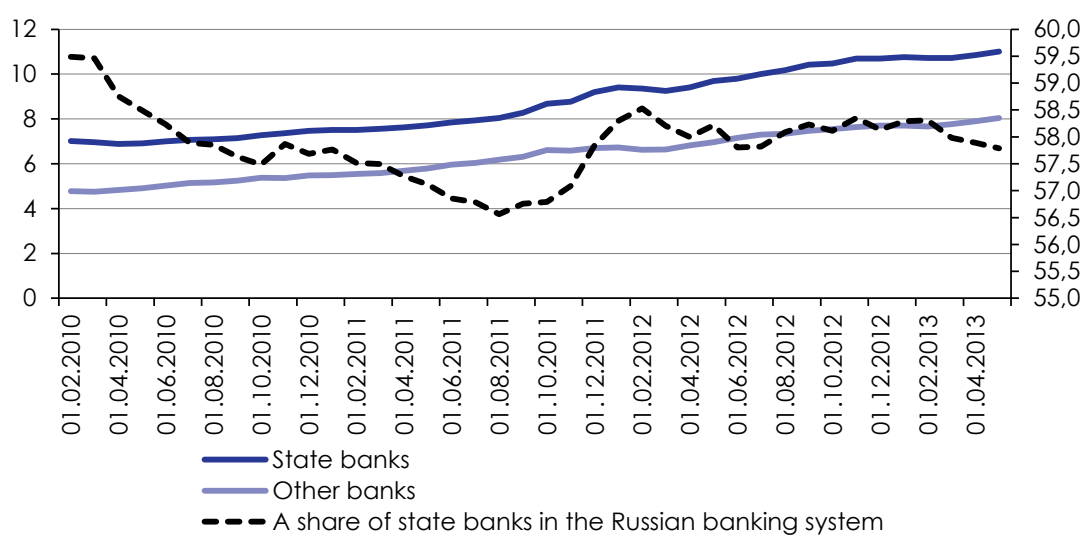

Fig. 6. Dynamics in state and other banks' corporate loans (Rb trillion), and a share of state banks in the corporate loan market (\%, right-hand grid)
A combination of high interest rates and a substantial nominal volume of indebtedness entailed a heavier debt burden upon household income. In Q1 2013, scheduled (according to loan repayment schedules) household expenditures on bank loan service accounted for $12 \%$ of disposable household income ( $\mathrm{Rb}$ 976bn) against $9 \%(\mathrm{Rb} 473 \mathrm{bn})$ at the height of the crisis in Q1 2009.

Higher debt burden upon household income degraded the quality of retail credit portfolio. A share of retail loans in arrears and volume of provisions for losses on retail loans began to grow early in the year. These values grew up in response to a higher growth rate in values of the loans in arrears and the provisions rather than slower growth in total credit portfolio. For example, the value of loans in arrears increased 15\% since May 1, 2013 against just 6\% during the preceding year.

The retail credit portfolio might grow at slower rates with gradual deterioration of its quality by the end of year. The occurrence of a large-scale bad debt crisis in this loan market segment will depend on the dynamics in household income and financial ability to timely discharge obligations to banks.

Lending to corporate customers kept slowing down. Loans in arrears increased $1.7 \%$ (Rb $311 \mathrm{bn}$ ) in April, whereas annual growth rates in loans in arrears declined to $13.4 \%$, being equal to the value observed early in 2011. Nevertheless, the quality of credit portfolio remained stable in the corporate segment of the market. Loans in arrears remained at $4.4 \%$, while loan loss provisions accounted for $7.2 \%$ of total credit portfolio.

Table 2

RUSSIAN BANKING SYSTEM'S STRUCTURE OF ASSETS (AT MONTH END), AS \% OF TOTAL

\begin{tabular}{l|c|c|c|c|c|c|c|c|c|c|c|c|c|c|c|} 
& 12.08 & 12.09 & 12.10 & 12.11 & 03.12 & 06.12 & 09.12 & 10.12 & 01.13 & 02.13 & 03.13 & 04.13 \\
\hline $\begin{array}{l}\text { Assets, Rb trillion } \\
\begin{array}{l}\text { Cash } \\
\text { and precious metals }\end{array}\end{array}$ & 28022 & 29430 & 33805 & 41628 & 41533 & 44266 & 45861 & 47096 & 48429 & 49165 & 49839 & 50693 \\
\hline $\begin{array}{l}\text { Deposits in the Bank } \\
\text { of Russia }\end{array}$ & 7.5 & 6.7 & 2.7 & 2.9 & 2.4 & 2.5 & 2.6 & 2.6 & 2.6 & 2.5 & 2.5 & 2.7 \\
\hline $\begin{array}{l}\text { Interbank operations } \\
\text { Foreign assets }\end{array}$ & 5.2 & 5.4 & 6.5 & 4.2 & 3.2 & 3.0 & 2.8 & 2.7 & 2.9 & 3.1 & 3.3 & 3.0 \\
\hline
\end{tabular}


Table 2, cont'd

\begin{tabular}{|l|c|c|c|c|c|c|c|c|c|c|c|c|}
\hline & 12.08 & 12.09 & 12.10 & 12.11 & 03.12 & 06.12 & 09.12 & 10.12 & 01.13 & 02.13 & 03.13 & 04.13 \\
\hline Households & 15.5 & 13.1 & 13.0 & 14.4 & 15.3 & 16.0 & 16.8 & 16.8 & 17.3 & 17.3 & 17.4 & 17.7 \\
\hline Corporate sector & 44.5 & 44.5 & 43.6 & 44.0 & 44.4 & 43.6 & 43.4 & 42.9 & 42.3 & 42.1 & 41.9 & 41.5 \\
\hline State & 2.0 & 4.2 & 5.1 & 5.0 & 4.9 & 3.8 & 3.3 & 3.2 & 3.7 & 3.3 & 3.2 & 2.9 \\
\hline Property & 1.9 & 2.7 & 2.6 & 2.3 & 2.4 & 2.3 & 2.3 & 2.3 & 2.3 & 2.3 & 2.2 & 2.2 \\
\hline
\end{tabular}

Source: Central Bank of Russia, IET's estimates. 